\title{
Assertiveness and Performance Tasks
}

\author{
Dr. Jerald C. Moneva \\ Department of Education \\ Mandaue City Division, Cebu, Philippines \\ E-mail: monevajerald5@gmail.com \\ Nicole G. Bolos \\ Jagobiao National High School \\ North Road, Jagobiao Mandaue City \\ E-mail: nicolebolos13@gmail.com
}

Received: February 10, 2020

Accepted: March 26, 2020 Published: April 13, 2020

doi:10.5296/ijssr.v8i2.16839

URL: http://dx.doi.org/10.5296/ijssr.v8i2.16839

\begin{abstract}
Assertiveness is defined as a behavior in which an individual is confident and can express thoughts, feelings, and opinion in direct honest way. Whereas, performance task pertains to an activity which students are asked to perform or demonstrate their understanding. This study aims to assess the association between assertiveness as independent variable, and level of performance task as dependent variable using descriptive correlation design. The respondents are the senior high school students of Jagobiao National High School. Checklist is used as research instrument of the study. The data are analyzed through Chi-square test as statistical treatment. The result of this study shows that Jagobiao National High School students have high correlation between the two variables. To simplify the idea, level of assertiveness can influence the students' performance in school.
\end{abstract}

Keywords: assertiveness, performance tasks, students 


\section{Rationale}

Adolescence is a stage in life when a person is in between of childhood and adulthood. According to Robards \& Bennett (2013), adolescence is a significant period of life which is generally characterized by complex and natural process within social, economic, political and cultural context. Students in this stage face different responsibilities, either at home or at school. When it comes to attitude, adolescents have this assertive behavior. Assertiveness is a specific behavior in which an individual is confident and can express thoughts, feelings and opinion in direct honest way. When you speak assertively, it shows that you believe in yourself and you can stand up for your own. According to Ames, Lee, \& Wazlawek (2017), a person's attitude primarily reflects one's inspirations and values to move forward or getting along. In other situations, intuitions of a person that a bad or good thing will happen dictates the degree of aggressiveness he/she applies. Also at some cases, conflicts or violence arise as a cause of failing to maintain feelings and emotions. The point is whatever causes a person's behavior, there is some reasons to be hopeful about the challenge of assertiveness. Arguments and negotiation skills can be learned. This fact receives support from scientist and practitioners who have collected a body of knowledge about good practices that can help people state themselves effectively.

On the other hand, performance task is an activity that the students are asked to perform or demonstrate their understandings. Its complexity is more than quizzes and examinations because academic lessons are contextualized to relate in situations to help students grasp more on the concepts or ideas in each learning competency. According to Espinosa (2015), students should be given chances to show their understanding and skills through performance tasks.

It is concluded that effective communication skills training helps in reducing rumination or repeated contemplation. However, this process is not effective in lessening on blaming others. Overall, cognitive behavioral training program can increase the use of problem-focused coping responses and some cognitive strategies focused on planning, refocusing, positive appraisal in containing emotions (Allahyari \& Jendabadi, 2015). It was found that an association between assertiveness and mental was existed and the significance of being assertiveness, and saying no, in psychological well-being. When there is higher assertiveness, then there would be better mental health (Pourjali \& Zarnagnash, 2010). It was also found that major influence of development of assertiveness and self-esteem of adolescents are age and the education level. As the age and education level increase the level of assertiveness and self-esteem also increased (Shanmugan \& kathyayini, 2017).

Having an assertive behavior is important. In a classroom setting, it has been observed that each of the students have different approaches in doing performance tasks. Some are eager to do their task and communicate to other people while some are not when it comes to their performance task during group activities. It has also been observed that there are some that don't participate and depend to their respective leaders while some are showing their assertive behavior by giving help and ideas. Most of the students in Jagobiao National High School are given different performance tasks in order to assess their understanding in a 
particular lesson. Some students have this attitude that they only do the required tasks during deadlines. However, there are still students who do their tasks with so much effort and prefer to pass it on time. Some students also try to help others. The behavior of students inside the classroom is quite different to their outside behavior. They know how to set aside things, and how to prioritize things that are important most especially in the classroom. In addition, there are some cases that the performance task of students should be done by group. With that, there is a possibility that a good student will be grouped with tardy students. Some students in that situation use their assertive behavior to communicate with their groupmates and convince them to do the task, and cooperate in order to achieve a good performance. These various types of students can be observed to be present in Jagobiao National High School. In general, different students have their own ways to respond on the situations they are into.

This study is important because it will know the correlation between assertiveness and level of performance task of Senior High School students in Jagobiao National High School. It can also identify the things to consider in the development of assertive behavior and performance task.

\subsection{Theoretical Background}

The study is supported by "Philosophies of Assertiveness" of Earl Peter Malarchick (1976). The theory explains the philosophical assumptions of assertiveness. The personal growth to assertiveness will also be examined and communication techniques will be discussed to enhance one's personal growth through being assertive.

Philosophies of assertiveness focuses on changing one's behavior and observing that change can enhance one's self-concept. This theory indicated that a person doesn't need to show assertive behavior to enhance or maintain one's self-concept or level of personal growth, even though in some instance assertive behavior may be helpful in student's studies. It also pays attention to assertiveness that refers to 'being' or 'personal growth' and to recognize the difference to a possible interrelationship of assertive behavior and being.

As the researcher observed, the behavior of the students affect their studied because when it talks about performance tasks it needs an ability to perform and demonstrate. There are performance tasks that can be done individually and by group. If it's individual, students tend to get stress and frustrated because there are things that the students don't know how to do or confused with their work. While on the group activity, students can rely on each other so their work are more lessen and become easier. Students who can ask help to others is more effective when it comes to performance tasks. With the help of the others, group activities is easier than individual. When group activity, the students can divide their task and submit it on time. Than individual, students then to focus more to that certain activity given, therefore performance tasks depend to the behavior and willingness of the students. They rely to the things they know and didn't know or to the task that is given if it's easy or difficult. In one hand, performance task can help students to improve their skills which can help then in the future.

Performance task is an activity that needs to be performed well. In order for the students to 
have a good level of performance task student should develop and gain assertive behavior in doing such. Personal growth is one of the indicators that student's performance in school will develop. It helps students to be assertive and actively participate in every activity in school. To excel in performance tasks, students must enhance their personal growth and assertive behavior

\subsection{Statement of Purpose}

The study aims to determine the level of assertiveness of students, level of performance task of the students and the correlation between assertiveness and level of performance task among grade 11 and 12 students of Jagobiao National High School.

\subsection{Review of Related Literature}

This research study was supported by different articles gathered by the researcher.

According to Ames, Lee, and Wazwalek (2017), there are some cases that our behavior reelects the value that we have. There are times that we face a lot of consequences in school for example, but because of the challenge of assertiveness students are still able to think positive things in which can lead them to improve their skills and learned from it. According to Plafman (2017), assertiveness is a body of research that has now studying many disciplines such as health care, sports and organizational studies. In addition, according to Maric and Ferjan (2010), assertiveness can help boast one's power as a person yet to much assertiveness cannot make you powerful. According to Pourjalill (2010), the importance of assertiveness has existed in psychological well-being. Practicing assertiveness can help mental health to become better. According to Allahyari and Jenaabadi (2015), studies have shown that assertiveness and self-assertion affect how students regulate their self's emotion. According to Prakash and Devi (2015), assertiveness is an important behavior that every students must have and learn how to develop in order for them to achieve more in their education and personality. With that, according to Parray and Kumar (2016), schools can have programs that can enhance assertive behavior in adolescence. Assertiveness training can develop assertive behavior. According to Parray, Kumar, and Ahirwar (2018), it is really needed for adolescents to have assertiveness training, because assertiveness help students to be better in their education and personality development, in this way they can able to express their feelings and thoughts in the correct way. According to Ghodrati, Tavakoli, Heydari, and Akbarzadeh (2016), to develop more in achieving academics, assertiveness should be first put in elementary and high school because it is a learnable skill. According to Sitota (2018), the more assertive a student is, the more motivated he/she is in achieving more in his/her studies, however the level of assertiveness among males is way better than female students. In addition according to Apostol (2017), the performance of students in speech and oral communication is not influenced by how assertive the students are as well as their level of self-esteem. Therefore, according to Shanmugan and Kathyayini (2017), there is greatly an association between the age and the level of education of an adolescent and the level of assertiveness as well as self-esteem. However, according to Radmila (2019), social anxiety among students can be lessen if there will be programs practicing and exercising assertiveness behavior implemented. 
According to Espinosa, Moneterola, and Punzalan (2013), the longer the students are exposed to overloaded tasks, the more they are interested to do performance tasks. According to Parkesn (2010), teachers could research studies that would give them informations about what exactly excellent performance and expect it to their students. According to Daghan and Akkoyunlu (2014), if performance based assessment methods are used to evaluate the performance task of the students, the students would be able to take responsibility with a certain task. According to Farooq, Chaudhry, Shafia, and Berhanu (2011), to help the students achieve high level of performance task is to understand the factors that may contribute to the students' academic success. According to Tripathy and Srivastava (N.D), students will be able to move confident in giving their best in any performances task in school if they have achieved academic achievements in school. Also according to Akessa and Ohufera (2015), on looking in to the level of performance task of a student, it should not be based only by the performance itself but also into the social economic status of the student because it is one of the factors that affect students' academic performance. According to Espinosa (2015), students may achieve development in their performance if they are enhanced in improving their skills through letting them make essays, compositions and others. According to Wren (2015), providing questions to the students and giving them enough time to think about the answer of a certain question could help in evaluating students understanding in learning. In addition, according to Khajepour and Ghazini (2011), parents involving themselves to their learning children are important in every student's education. According to Benner, Boyle, and Saddler (2016), providing assistance at home with homeworks and school projects does not give such an importance to students in achieving a good level of performance at school. According to Doodman, Zadeh, and Changizi (2017), it could also help the students to be more focused on such activities or in school if they feel valued by their parents. Therefore, according to Mushtaq and Khan (2017), the factors that affect student's level of performance task at school are communication, proper guidance from professionals or other adults and family stress. However, according to Ratnasari and SalimAndriansyah (2014), not all the time that self-confidence could positively affects the performance of students at school.

\section{Research Method}

This chapter discusses about the design, research environment, research respondents, research instruments and data gathering that will be used in progression of the research study.

\subsection{Design}

The study was designed to find out the descriptive correlation between assertiveness and level of performance tasks

\subsection{Environment}

This study was conducted in Jagobiao North Road Mandaue City. In the School of Jagobiao National high School in Senior High School department and was built in 1984. Jagobiao Senior High School Department has its own 2 building in each building every floor has 2 room the first building near the ground consist of faculty room, computer laboratory, accountancy business management 11 (ABM 11), General Academic Strand 11 (GAS 11), 


\section{Macrothink}

Humanities and Social Sciences 11 (HUMSS 11) AND Technical Vocational Livelihood 11 (TVL 11) classrooms and on the second consist of ABM 12, GAS 12, HUMSS 12, and STEM 12 classrooms

\subsection{Respondents}

The respondents of this study are the 250 total population students of Jagobiao Senior High School Department but only 245 students answered the questionnaire.

\subsection{Instruments}

Checklist is the chosen research instrument for data collection of this study the checklist consists of prepared list of ten (10) items for the first variable and another 10 for the second. The checklist will provide the information in the problem 1-3 stated in statement of the purpose. The information obtained could help the researcher when interpreting the result.

\subsection{Data Gathering Procedures}

The researcher will ask permission to the school head and adviser also, the researcher will ask for the participation of the students to be the respondents of the study with thee help of the transmittal letter signed by the school head and teachers involved. Collecting the data will be on September 9-20 2019 in Jagobiao National High School. The questionnaire will be printed in $1 / 2$ of bond paper first part in front and second part at the back. The researcher will provide an answer sheet for the respondents. After answering the questionnaire the researcher will collect all the questionnaire and it will be the basis for the researcher in making the analysis, interpretation, findings, conclusion, and recommendation of the study.

\subsection{Statistical Treatment}

The researcher used weighted mean and chi-square in interpreting the data. The chi-square will be used to determine the relationship between assertiveness and level of performance tasks and the null hypothesis (Ho) represent a relationship. While (H1) represent no relationship. 


\subsection{Data Analysis and Discussion}

Table 1. Assertiveness

\begin{tabular}{lll}
\hline INDICATORS & WM & Interpretation \\
\hline 1. I express my opinions even if others disagree with me & 3.30 & Always \\
2. I stand for my rights and feelings whenever a person criticizes me & 3.56 & Always \\
3. I speak in front of a group of people confidently & 3.16 & Sometimes \\
4.I'm comfortable with face to face conversations & 3.44 & Always \\
5. I prefer to participate than to observe & 3.21 & Sometimes \\
6. I am not afraid to face any task that required for me to do & 3.38 & Always \\
7. I tell people how I feel & 3.35 & Always \\
8. It's hard for me to agree when other person idea doesn't fit to mine & 3.25 & Sometimes \\
9. In a conversation I interrupt the other person if he/she speaks nonsense things & 3.07 & Sometimes \\
10. I am willing to do things just to get what I want & 3.25 & Sometimes \\
Overall weighted mean & 3.30 & always \\
\hline
\end{tabular}

Scale: (1.00-1.80) Never; (1.81-2.60) Seldom; (2.61-3.40) Sometimes; (3.41-4.20) Often; (4.21-5.00) Always.

The table one showed that 10 of the indicator that was rated as Always, Often, Sometimes, Seldom and Never had the three highest and lowest weighted mean and it was interpreted as Always. The first highest weighted mean was 3.38 in which it states that students are not afraid to face any task that required for me to do. The second highest weighted mean is 3.44 and last highest weighted mean was 3.56. The first lowest weighted mean was 3.21 in which it was interpreted as sometimes where in it stated that students prefer to participate than to observe. The second lowest weighted mean is 3.16 and it was interpreted as sometimes in which it states that students sometimes feel confident in speaking in front of a group of people. The last lowest weighted mean was 3.07 and it was interpreted as sometimes. While the overall weighted mean was 3.30 and was interpreted as always. According to Sitota (2018) the more assertive a student is, the more he is in achieving in his studies. According to Allahyari \& Jenaabadi (2015) studies have shown that assertiveness and self-assertion affects how students regulate their selves emotion. According to Paray \& Kumar (2016) schools can have programs that can enhance assertive behaviors in adolescents. Assertiveness training can develop assertive behavior. 


\section{Al Macrothink}

Table 2. Level of performance task

\begin{tabular}{lll}
\hline INDICATORS & WM & Interpretation \\
\hline 1. I like to join extracurricular activities & 3.51 & always \\
2. I make sure that my projects would be presentable and worth it & 3.79 & always \\
3. I like to participate whenever a teacher ask question & 3.25 & always \\
4. I participate school activities & 3.40 & always \\
5. I spend my vacant time doing school outputs and projects & 3.13 & sometimes \\
6. I submit outputs before deadline & 3.35 & always \\
7. I make sure that I have completely done and submit my outputs & 3.65 & always \\
8. I am positive on doing the task given & 3.57 & always \\
9. I review my report whenever we will have our reporting & 3.70 & always \\
10. I participate culminating activities whenever they need a representative & 3.19 & sometimes \\
Overall weighted mean & $\mathbf{3 . 4 6}$ & Always \\
\hline
\end{tabular}

Scale: (1.00-1.80) Never; (1.81-2.60) Seldom; (2.61-3.40) Sometimes; (3.41-4.20) Often; (4.21-5.00) Always.

The table two showed that 10 of the indicator that was rated as Always, Often, Sometimes, Seldom and Never had the three highest and lowest weighted mean and it was interpreted as Always. The first highest weighted mean was 3.65 followed by 3.70 in which it states that students always review their report they will have a reporting. According to Tripathy (2012) students who have a high level of academic achievements showed that they have a high level of assertiveness. The last highest weighted mean was 3.79 where in it states that students always make sure that their projects are presentable and worth it. According to Espinosa (2015) it is important to give students a performance task for it is an opportunity The first lowest weighted mean was 3.25 and it was interpreted as always followed by the second lowest weighted mean 3.19 and it was interpreted as sometimes and the last lowest weighted mean was 3.13 and it was interpreted as sometimes. While the overall weighted mean was 3.46 and was interpreted as always.

Table 3. Assertiveness and Level of Performance Tasks

\begin{tabular}{llll}
\hline & Value & df & Asymp. Sig. (2-sided) \\
\hline Pearson Chi-Square & $1.508 \mathrm{E} 3 \mathrm{a}$ & 928 & .000 \\
Likelihood Ratio & 568.818 & 928 & 1.000 \\
Linear-by-Linear Association & 101.087 & 1 & .000 \\
N of Valid Cases & 238 & & \\
\hline
\end{tabular}

a. 990 cells $(100.0 \%)$ have expected count less than 5 . The minimum expected count is .00 .

Based on the table above it implied that there is an association between dependent and independent variables because the alpha $(0.05)$ is greater than the p-value $(0.000)$. It means 
that level of assertiveness can influence to students performance task in school. Thus, there is a positive relationship between assertiveness and level of performance tasks. According to shanmugam \& Katyayini (2017) there is greatly an association between the age and the level of education of an adolescents and the level of assertiveness as well as self-esteem. According to (Ghodrati, Tavakoli, Heydari \& Akbarzadeh (2016) to develop more in achieving academics, assertiveness should be first put in elementary and high school because it is a learnable skill. According to Apostol (2017) the performance of the students in speech and oral communication is not influenced by how assertive the students are but also as well as their level of self-esteem.

\section{Findings}

From the study being conducted, the researcher found out that the students from Jagobiao National High School have a high level of assertiveness towards their performance tasks.

The researcher found out that the level of students' performance tasks was high for the students have gained a high interest towards their students that can make them assertive.

There is a high correlation between the two variables which are the assertiveness and level of performance task.

Therefore, students get interested in doing their performance tasks even though they have overloaded tasks in school because they are assertive in doing them that can lead them to have a better outcome or performance in school.

\section{Conclusion}

Every adolescent has an approach in dealing with particular task. One of which is assertive behavior. Assertiveness is an ability to affirm their decisions and actions to accomplish desired outcomes. This could be used in planning and carrying out tasks given. In addition, performance task are given to students to challenge themselves to put lessons in a context, ideally, real life applications. It is also to give students chance to show their skills of what they've understood to the lesson that has been tackled. Assertiveness greatly helps adolescent to their performance task. Based on the findings, students in Jagobiao Senior High School are able to increase the level of their performance task for they have a high level of assertiveness that can help them to improve their knowledge and understanding to a certain subject. It shows that the level of assertiveness can influence to students performance task in school for both variables have a significant correlation with each other. With that, the students are able to present a better output in their performance tasks for they have a high level in it can help them to perform well in school and that can help them to build a better future and can lead them to have a successful career as a result.

\section{Recommendation}

Based on the study conducted, the researcher recommends the research findings to the following:

For the students of Jagobiao National High School in Senior High School Department, and 
for them to be able to increase their level of assertiveness.

For the teachers of Jagobiao National High School, for them to help their students to have an idea on what aspect that the teacher can help their students and how they can help them.

For the future researcher of Jagobiao National High School, for them to have a credible source that might help them in the development of their research studies.

\section{References}

Akessa, G., \& Dhufera, A. (2015). Factors that influences students' academic performance: A case of rift valley university, jimma, ethiopoa. Journal of Education and Practice, 6(22), 55-64. Retrieved from https://www.ijste.org/

Allahyari, B., \& Jenaabadi, H. (2015). The role of assertiveness and self-assertion in female high school students' emotional self-regulation. Creative Education, 1616-1622. https://doi.org/10.4236/ce.2015.614163

Ames, D., Lee, A., \& Wazlawels, A. (2017). Interpersonal assertiveness: inside the balancing act. Soe Personal Psychology Compass, 1-16. https://doi.org/10.1111/spc3.12317

Apostol, E. (2017). Assertiveness, self-esteem and academic performance in speech and oral communication of Filipino junior secondary teacher education students. Asia Pacific Journal Multidisciplinary Research, 5(3). Retrieved from https://www.apjmr.com

Benner, A., Boyle, A., \& Sadler, S. (2015). Parental involvement and adolescents educational success: the roles of prior achievement and socio-economic status. Springer Science \& Business Media New York.

Daghan, G., \& Akkoyunlu, B. (2014). A qualitative study about performance-based assessment methods used in information technologies lesson. Educational Consultancy and Research Center, 14(1), 333-338. https://doi.org/10.12738/estp.2014.1.2005

Doodman, P., Zadeh, M. A., \& Hangiti, B. (2017).m Study the relationship between Self-esteem and academic achievement among high school students in lamerd city. International Journal of Scientific Study, 3(5), 221-226.

Espinosa, A., Monterola, S., \& Punzalan, A. (2013). Career-oriented performance tasks: Effects on students' interest in chemistry, Asia-Pacific Forum on Science Learning and Teaching, 14(2). https://doi.org/10.1155/2013/834584

Espinosa, L. (2015). Effective use of performance-based assessments to identify English knowledge and skills of efl students in educator. Theory and Practice in Language Studies, 12(5), 2441-2447. https://doi.org/10.17507/tpls.0512.02

Farroq, M., Chaudhry, A. H., Shafiq, M., \& Berhance, G. (2011). Factors affecting students quality of academic performance: A case of secondary school level. Journal of Quality and Technology Management, 2(7), 1-14. Retrieved from https://www.researchgate.net/publication/284150574 
Ghodrati, F., Tavakoli, P., Heydari, N., \& Akbarzadeh, M. (2016). Investigating the relationship between self-esteem, assertiveness and academic achievement in female high school students. Health Science Journal, 4(10), 1-5. Retrieved from https://www.imedpub.com/

Khajehpour, M., \& Ghazvini, S. D. (2011). The role of parental involvement affect in children's academic performance. Procedia Social and Behavioral Sciences, 1204-1208. https://doi.org/10.1016/j.sbspro.2011.03.263

Marie, M., \& Ferjan, M. (2010). Assertiveness as a determinant of an individual's power. International Conference on Organization Science Development. Retrieved from https://www.researchgate.net/publication/273137039

Mushtaq, I., \& Khan, S. H. (2012). Factors affecting students' academic performance. Global Journal of Management and Business Research, 9(12).

Parkes, K. (2010). Performance assessment: Lessons from performers. International Journal of Teaching and Learning in Higher Education, 22(1), 98-106. Retrieved from https://www.isetl.org/ijtlhe/

Parray, W. M., Ahirwar, F., \& Kumar, S. (2018). A study on assertiveness among rural adolescents. International Journal of Research and Analuctical Reviews, 5(4), 702-704. 101729/Journal.18666.

Parray, W., \& Kumar, S. (2016). Assertiveness among undergraduate students of the university The International Journal of Indian Psychology, 4(1), 283-291. Retrieved from https://www.researchgate.net/publication/316663003

Plafman, T. (2017). Assertiveness. Springer International Publishing, 1-7.

Pourjali, F., \& Zarnaghash, M. (2010). Relationship between assertiveness and the power of saying no with mental health among undergraduate student. Procedia Social and Behavioral Sciences, 137-141. https://doi.org/10.1016/j.sbspro.2010.12.126

Prakeish, N. R., \& Devi, N. (2013). Assertiveness behavior of undergraduate students. Scholar Research Journal of Interdisciplinary Studies, 2566-2575. Retrieved from http://www.ssjis.com

Radmila, M. (2019). Effects of an assertive behavior program on the reduction of anxiety in future teachers and preschool teachers. Psychology \& Psychological Research International Journal, 4(2), 3-9.

Shanmugan, J., \& Kathyayoni, N. (n.d.). Assertiveness and self-esteem in Indian adolescents. Galove International Journal of Health Sciences and Research, 4(2).

Sitota, H. (2018). Assertiveness and academic achievement motivation of adolescent students in selected secondary schools of Harari peoples refional state, Ethiopia. International Journal of Education \& Literacy Studies, 4(6), 40-46. https://doi.org/10.7575/aiac.ijels.v.6n.4p.40

Tripathy, M., \& Srivastava, S. (2012). To study the effect of academic achievement on the 


\section{Macrothink}

International Journal of Social Science Research

ISSN 2327-5510

2020, Vol. 8, No. 2

level of self-confidence. International Journal of Yoga and Allied Sciences, 1, 33-45.

Wren, D. (2015). Assessing 21st-century skills with performance tasks: The five-year journey of a large school division. Virginia Educational Leadership, 37-55. Retrieved from https://www.vaascd.org/

\section{Glossary}

To further understanding of the problem, the researcher defines the following terms.

Assertiveness is a specific positive behavior in which a student has an ability to express and respond on every situation in a calm and positive way.

Performance Task is an activity in which the students are ask to perform or demonstrate in school and there are other activities related to performance task like quizzes, projects, reporting, assignments, and others.

\section{Appendix}

\section{PART I}

\section{ASSERTIVENESS}

Instruction: Read each item carefully and rate according to your preference.
5- Always
4-often
3-Sometimes
2-Seldom
$1-$ Never

\begin{tabular}{l}
\hline INDICATORS \\
\hline 1. I express my opinions even if others disagree with me. \\
2. I stand for my rights and feelings whenever a person criticizes me. \\
3. I speak in front of a group of people confidently. \\
4. I'm comfortable with face to face conversations. \\
5. I prefer to participate than to observe. \\
6. I am not afraid to face any task that required for me to do. \\
7. I tell people how I feel. \\
8. It's hard for me to agree when other person idea doesn't fit to mine. \\
9. In a conversation I interrupt the other person if he/she speaks nonsense things. \\
10. I am willing to do things just to get what I want. \\
\hline
\end{tabular}

\section{PART II}

\section{LEVEL OF PERFORMANCE TASK}

\begin{tabular}{llllll}
\hline INDICATORS & 5 & 4 & 3 & 2 & 1 \\
\hline 1. I like to join extracurricular activities. & & & & & \\
2. I make sure that my projects would be presentable and worth it. \\
3. I like to participate whenever a teacher ask question.
\end{tabular}


4. I participate in school activities.

5. I spend my vacant time doing school outputs and projects.

6 . I submit outputs before deadline.

7. I make sure that I have completely done and submit my outputs.

8. I am positive on doing the task given.

9. I review my report whenever we will have our reporting.

10. I participate in culminating activities whenever they need a representative.

\section{Copyrights}

Copyright for this article is retained by the author(s), with first publication rights granted to the journal.

This is an open-access article distributed under the terms and conditions of the Creative Commons Attribution license (http://creativecommons.org/licenses/by/4.0/). 